\title{
Kelimpahan Spesies Lalat Buah (Diptera: Tephritidae) dan Parasitoidnya yang Berasosiasi pada Tanaman Belimbing (Averrhoa carambola L.) di Kabupaten Gianyar
}

\author{
I NYOMAN WIDNYANA PUTRA, I WAYAN SUSILA*), DAN \\ I GUSTI NGURAH BAGUS
}

\author{
Program Studi Agroekoteknologi Fakultas Pertanian Universitas Udayana \\ J1. PB. Sudirman, Denpasar 80231 Bali \\ ${ }^{*}$ E-mail: w1sus@yahoo.com
}

\begin{abstract}
Abundance of Fruit Fly Species (Diptera: Tephritidae) and Its Parasitoid Associated on Star Fruit Plants (Averrhoa carambola L.) in Gianyar regency. This study was conducted to determine the abundance of fruit flies, and itsspecies of parasitoid on starfruit plants in Gianyar regency. Samples of star fruit attacked by fruit fly was taken purposively. The purpose of this study was to know the abundance, composition, and percentage of damage, kinds of parasitoid and parasitization rate. The results showed that was found 2 kinds of fruit flies, that are Bactrocera. carambolae and B. papayae. B. carambolae was dominant in all districts in Gianyar Regency compare them $B$. papayae. In Sukawati district was 64\%, (492 adults), Blahbatuh district was 59.817\% (460 adults), Ubud district was $61.528 \%$ (491 adults), Payangan district was 55.476\% (390 adults), Tampaksiring district was $55.001 \%$ (390 adults), respectively. Meanwhile, B. papayae in Sukawati district was $35.348 \%$, (269 adults), Blahbatuh district was 40.182\% (309 adults), Ubud district was $38.471 \%$ (307 adults), Payangan district was $44.523 \%$ (313 adults) and Tampaksiring district was $40.998 \%$ ( 271 adults), respectively. The average of damage percentage was $86.33 \%$. There are 3 kinds of parasitoids associated on fruit flies in starfruit plants in Gianyar regency. The parasitoid are Diachasmimorpha sp, Opius sp. and Fopius arisanus. The average parasitization rate was $11.12 \%$, with the highest parasitization rate in Ubud district was $12.40 \%$ and the lowest in Tampaksiring districtwas $9.58 \%$.
\end{abstract}

Keywords: fruit fly, parasitoid, star fruit

\section{PENDAHULUAN}

Indonesia memiliki banyak ragam jenis buah karena Indonesia terletak di daerah katulistiwa yang mempunyai tipe iklimtropis (Whitmore, 1980). Ditemukan sebanyak 329 jenis buah asli Indonsia yang tumbuh liar di hutan maupun yang telah dibudidayakan. Buah-buahan asli Indonesia ini tergolong dalam jenis pohon, liana, perdu, herba dan semak. Tanaman belimbing merupakan salah 


\section{NYOMAN WIDNYANA PUTRA. et al. Kelimpahan Spesies Lalat Buah (Diptera: Tephritidae)...}

satu jenis tanaman yang kebanyakan masih ditanam sebagai tanaman perumahan baik digunakan sebagai tanaman hias dan buahnya hanya untuk konsumsi keluarga. Apabila tanaman belimbing dibudidayakan dengan baik akan memiliki nilai ekonomi yang cukup tinggi. Budidaya tanaman belimbing menghadapi beberapa kendala yaitu dari segi fisik, lingkungan dan gangguan OPT (Organisme Pengganggu Tanaman). Salah satu hama yang sangat berpengaruh besar terhadap penurunan produksi buah belimbing adalah serangan lalat buah. Lalat buah (Diptera : Tephritidae) merupakan salah satu hama potensial yang sangat merugikan produksi buah-buahan dan sayuran, baik secara kuantitas maupun kualitas (Rouse et al., 2005). Kehilangan hasil yang diakibatkan oleh serangan hama lalat buah bervariasi antara 30-100\% bergantung pada kondisi lingkungan dan kerentanan jenis buah yang diserangnya (Gupta dan Verma, 1978). (Orr, 2002) melaporkan bahwa ada sekitar 90 spesies lalat buah di Indonesia bagian barat termasuk lalat buah jenis lokal (indegenous). Delapan spesies diantaranya merupakan hama penting yaitu Bactrocera albistrigata (de Maijere), B. dorsalis (Hendel), $B$. carambolae (Drew and Hancock), $B$. papayae (Drew and Hancock), B. umbrosa (Fabricius), B. (Zeugodacus) caudata
(Fabricius) dengan sinonim Bactrocera (Z) tau (Walker), Bactrocera (Z) cucurbitace (Coquillete) dan Dacus (Callantra) longicornis (Wiedemann). Perkembangan populasi lalat buah dialam dikendalikan oleh musuh alami yaitu parasitoid. Parasitoid mengendalikan populasi lalat buah dengan cara memparasit larvanya yang masih ada di dalam buah.Beberapa parasitoid yang menyerang Bactrocera juga ditemukan di Lombok (Ardiasningsih, 2006). Empat spesies parasitoid yang berhasil diidentifikasi yaitu spesies parasitoid Biosteres vandenboschi Fullaway (Bv), Opius makii Sonan (Op), parasitoid Chalcidoidea (Ch) dan Eurytomide $(\mathrm{Eu})$ yang ditemukan pada buah belimbing.

\section{BAHAN DAN METODE}

Penelitian ini dilakukan di lapang dan di laboratorium. Penelitian lapang dilaksanakan di Kabupaten Gianyar Bali dan penelitian laboratorium dilaksanakan di Laboratorium Pengendalian Hama dan Penyakit Terpadu Fakultas Pertanian Universitas Udayana, berlangsung selama tiga bulan mulai dari bulan Agustus 2017 sampai dengan bulan Oktober 2017. Percobaan ini mengunakan metode purposive sampling, yaitu pengambilan sampel dilakukan pada buah-buah yang memiliki 
gejala serangan lalat buah (yang sudah jatuh) secara langsung. Tempat pengambilan buah.

sampel meliputi Kecamatan Sukawati, Blahbatuh, Ubud, Payangan dan Kecamatan Tampaksiring.

\section{Alat dan Bahan}

Alat yang digunakan dalam penelitian ini adalah mikroskop, cawan petri, pinset, kuas, gunting, kain, kamera dan botol plastik transparan.Bahan-bahan yang digunakan dalam penelitian ini adalah tanah dan pasir sebagai media perkembangan pupa lalat buah dan sampel buah-buahan yang terserang lalat

\section{Metode Pengambilan Sampel}

Penentuan unit sampel di Kabupaten Gianyar dilakukan secara diagonal, sehingga didapatkan 5 unit sampel. Pada tiap-tiap unit sampel akan diambil 3 pohon belimbing dengan jarak minimal $3 \mathrm{~km}$. Pada masingmasing pohon akan diambil 10 buah yang terserang lalat buah. Interval pengambilan sampel dilakukan tiap 3 hari sebanyak 6 kali.

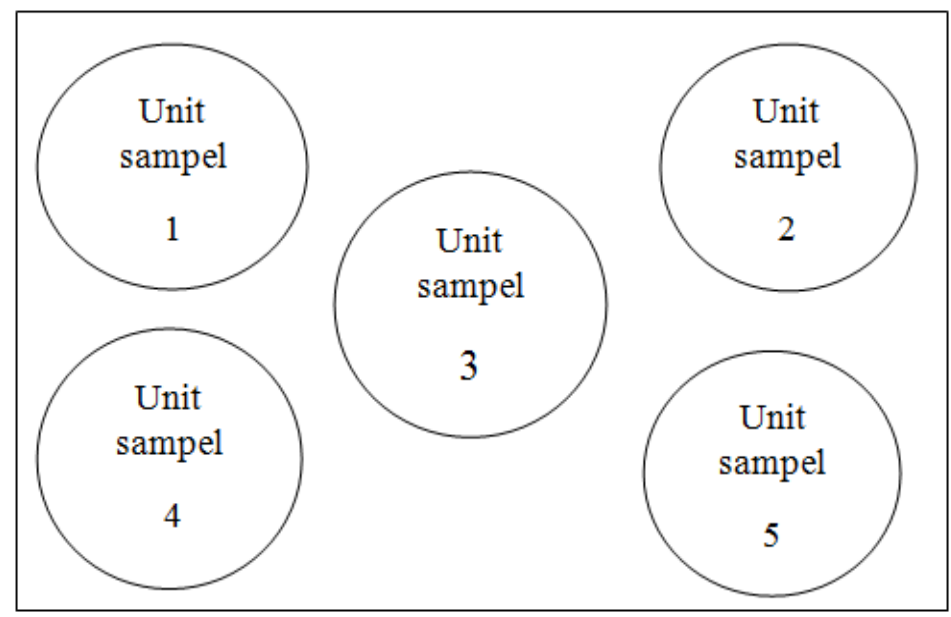

Gambar 1. Denah Pengambilan Sampel di Kabupaten Gianyar dengan Cara Diagonal

\section{Keterangan :}

1. Kecamatan Payangan

2. Kecamatan Tampaksiring

3. Kecamatan Ubud

4. Kecamatan Sukawati

5. Kecamatan Blahbatuh 
I NYOMAN WIDNYANA PUTRA. et al. Kelimpahan Spesies Lalat Buah (Diptera: Tephritidae)...

Metode Pemeliharaan Lalat Buah

Sampel buah belimbing yang sudah menunjukkan gejala serangan diambil dari lapang dan diletakan pada botol pemeliharaan dari plastik transparan dengan ukuran tinggi $23,5 \mathrm{~cm}$ dan diameter $8,5 \mathrm{~cm}$.

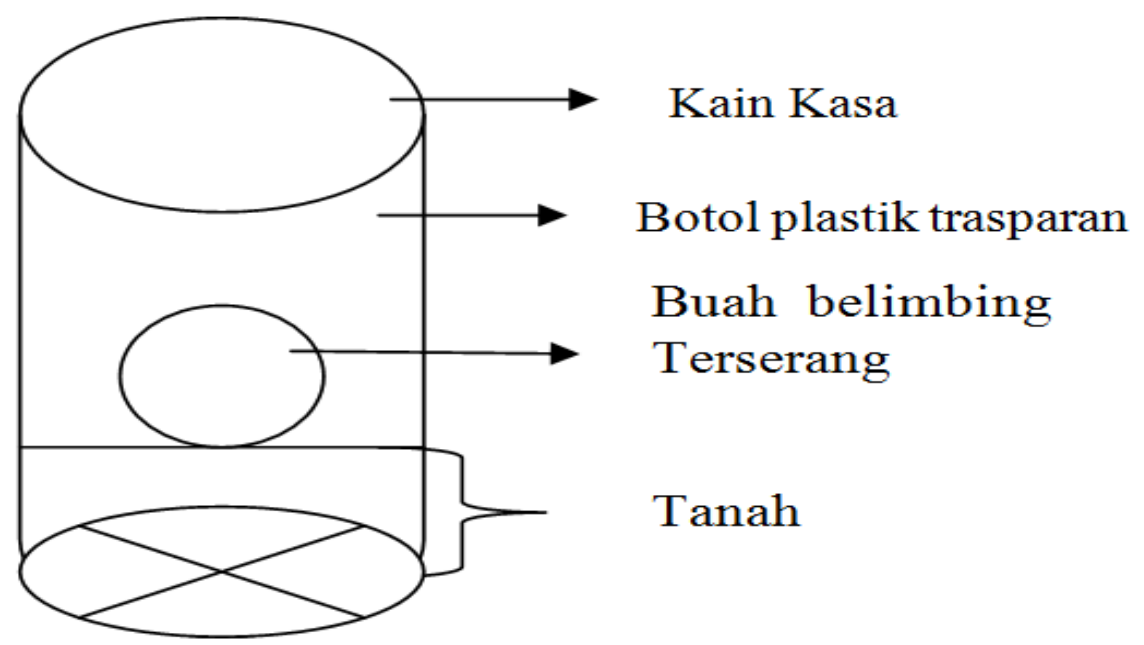

Gambar 2. Cara pemeliharaan lalat buah

Sebagai media terbentuknya pupa, baik terhadap lalat buah maupun parasitoid. maka di dalam botol diberikan media tanah Identifikasi dilakukan dengan menggunakan yang dicampur pasir dengan perbandingan mikroskop strio berdasarkan ciri-ciri 1:1 dengan tinggi $10 \mathrm{~cm}$ dan di atasnya morfologi yang dimiliki masing-masing diberikan kain kasa sebagai penutup dan spesies sesuai dengan (Drew et al, 1994 dan pentilasi. Pemeliharaan dilakukan sampai Suputa, 2006). Kelimpahan populasi lalat munculnya imago lalat buah dan parasitoid buah dan parasitoid pada buah belimbing dihitung dengan rumus sebagai berikut:

\section{Indentifikasi Lalat Buah dan Parasitoid}

Imago-imago yang muncul dari buah belimbing yang sebelumnya di tempatkan pada tempat pemeliharaan akan diidentifikasi 
AGROTROP, 9 (1): 1 - 12 (2019)

\section{Kelimpahan Populasi}

Kelimpahan $(K)=\frac{\text { Jumlah pesies yang ditemukan dilokasi } x}{\text { Jumlah keseluruhan spesies yang terdapat dilokasi } x} \times 100 \%$

\section{Persentase serangan lalat buah dihitung dengan rumus sebagai berikut}

$$
I=\frac{\text { Jumlah buah yang terserang }}{\text { Jumlah buah keseluruan }} \times 100 \%
$$

$I=$ Persentase serangan

\section{Tingkat parasitisasi dihitung dengan rumus sebagai berikut:}

$$
P=\frac{\text { imagoparasitoidA }}{\text { jumlah imago lalat buah }+ \text { jumlah imago parasitoid }(A+B+C)} \times 100 \%
$$

Keterangan :

$\mathrm{P}=$ Tingkat parasitisasi $(\%)$

Parasitoid = Jumlah Imago salah satu parasitoid yang muncul

Imago lalat buah = Jumlah total imago lalat buah yang muncul dari pupa yang tidak terparasitisasi.

\section{HASIL DAN PEMBAHASAN}

\section{Lalat Buah yang ditemukan}

Hasil penelitian menunjukkan terdapat 2 spesies Bactrocera spp. yang menyerang tanaman belimbing di Kabupaten Gianyar yaitu Bactrocera carambolae dan Bactrocera papaya (Tabel. 1).

\author{
Komposisi Populasi Lalat Buah pada \\ Tanaman Belimbing di Kabupaten \\ Gianyar \\ Hasil identifikasi menunjukkan ada \\ dua spesies lalat buah yang menyerang \\ tanaman belimbing di Kabupaten Gianyar \\ yaitu B.carambolae dan B. papayae.
}


I NYOMAN WIDNYANA PUTRA. et al. Kelimpahan Spesies Lalat Buah (Diptera: Tephritidae)...

Tabel .1. Karakter Morfologi dari Bagian-Bagian Tubuh

\begin{tabular}{|c|c|c|c|}
\hline \multirow[t]{2}{*}{ Spesies } & \multicolumn{3}{|c|}{ Morfologi } \\
\hline & Sayap & Abdomen & Toraks \\
\hline Bactrocera papayae & $\begin{array}{l}\text { Pita hitam pada garis costa dan } \\
\text { garis anal sangat jelas. }\end{array}$ & $\begin{array}{l}\text { Abdomen dengan } \\
\text { ruas-ruas jelas, tergit } \\
3 \text { terdapat garis } \\
\text { melintang. }\end{array}$ & $\begin{array}{l}\text { Warna hitam } \\
\text { dominan pada } \\
\text { skutum dan setae } \\
\text { terletak di ujung dan } \\
\text { diluar pita kuning, } \\
\text { skutum dengan pita } \\
\text { berwarna kuning/ } \\
\text { orange di sisi lateral. }\end{array}$ \\
\hline
\end{tabular}

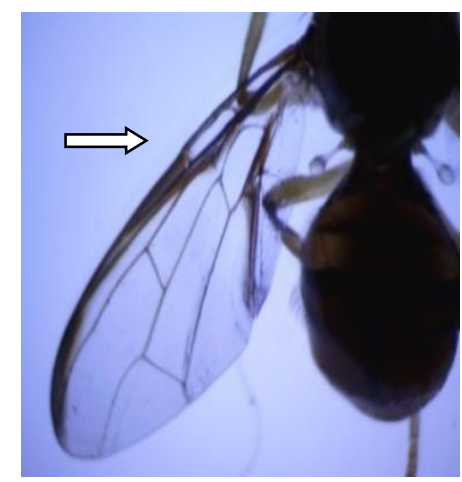

Bactrocera carambolae
Pita hitam pada garis costa dan garis anal sangat jelas.

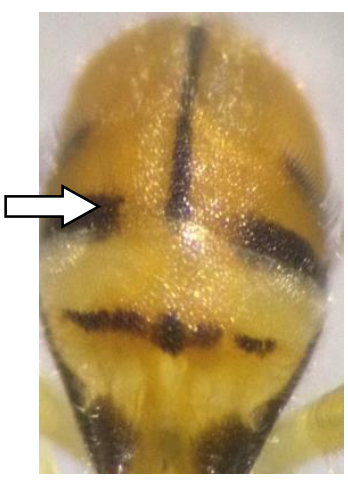

Abdomen dengan ruas-ruas jelas, tergit 3 terdapat garis melintang dan terdapat pola persegi di lateral abdomen.

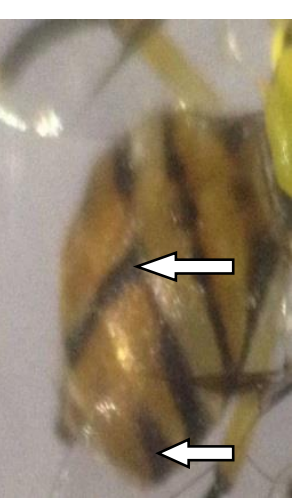

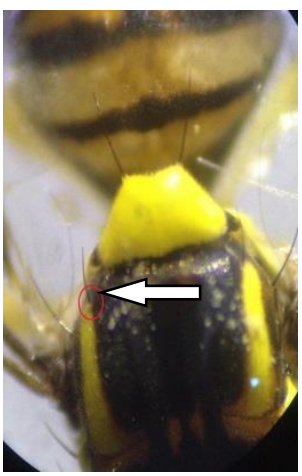

Warna hitam dominan pada skutum dan setae sebelum ujung pita kuning, skutum dengan pita berwarna kuning/ orange di sisi lateral

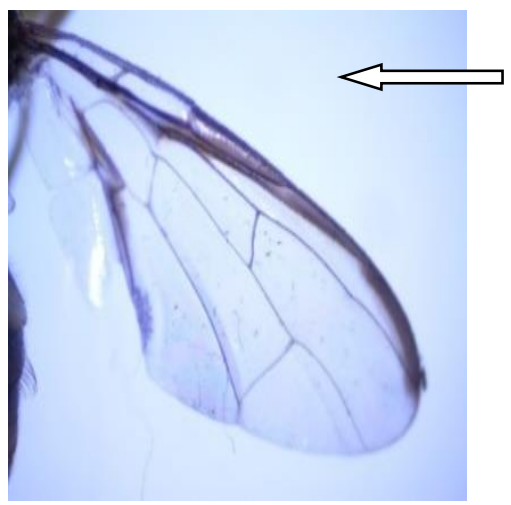




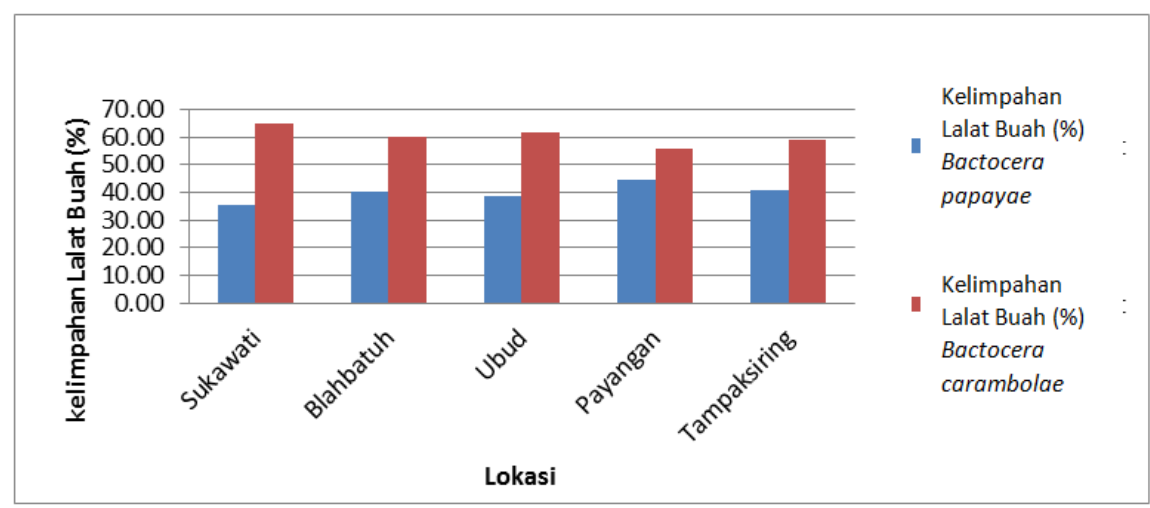

Gambar 3. Komposisi Kelimpahan Lalat Buah pada Tanaman Belimbing di Kabupaten Gianyar

B. carambolae mendominasi di semua Kecamatan di Kabupaten Gianyar (Gambar 3). Pada Kecamatan Sukawati $(64,651 \% ; 492$ imago), Kecamatan Blahbatuh (59,817\%; 460 imago), Kecamatan Ubud (61,528\%; 491 imago), Kecamatan Payangan (55,476\%; 390 imago), Kecamatan Tampaksiring (55,001\%; 390 imago) sedangkan B.papayae pada Kecamatan Sukawati (35,348\%; 269 imago), Kecamatan Blahbatuh (40,182\%; 309 imago), Kecamatan Ubud (38,471 \%; 307 imago), Kecamatan Payangan (44,523\%; 313 imago) dan Kecamatan Tampaksiring (40,998\%; 271 imago).Menurut White and Hancock (1997), $B$. papayae dan $B$. carambolae adalah spesies lalat buah yang bersifat polifagus dengan kisaran inang yang banyak. Kisaran inang $B$. carambolae dan $B$. papayae yaitu belimbing, belimbing wuluh, jambu air, jambu biji, tomat, cabe, nangka, cempedak, sukun, jeruk lemon, sawo, manggis, mangga, aren, ketapang dan lainlain. Kisaran inang yang banyak menyebabkan kedua spesies tersebut memiliki populasi yang tinggi.

Menurut Indriyani dkk. (2013), perbandingan nisbah kelamin sebesar 1:2 pada $B$. carambolae dan $1: 1$ pada $B$. papayae. Pada perbandingan nisbah kelamin, ditemukan jenis kelamin betina yang paling banyak. Semakin banyak betina maka populasi akan bertambah hal ini diduga akan semakin banyak telur yang akan diletakkan pada buah yang akan diserang.

Persentase Serangan Lalat Buah pada Buah Belimbing di Kabupaten Gianyar

Hasil penelitian menunjukan persentase serangan lalat buah pada buah belimbing di Kabupaten Gianyar bervariasi yaitu di Kecamatan Sukawati $87.78 \%$, Kecamatan Blahbatuh $90.56 \%$, Kecamatan Ubud 


\section{NYOMAN WIDNYANA PUTRA. et al. Kelimpahan Spesies Lalat Buah (Diptera: Tephritidae)...}

86.67\%, Kecamatan Payangan 82.78\%, dan Kecamatan Tampaksiring $83.89 \%$ dengan rata-rata $86,33 \%$ (Gambar 4). Tingginya persentase serangan lalat buah pada tanaman belimbing dipengaruhi oleh kelimpahan lalat buah yang tinggi. Banyaknya populasi lalat buah yang menyerang tanaman belimbing disebabkan karena tanaman tersebut merupakan tanaman rumah dan pekarangan yang jarang atau tidak pernah mendapatkan perlakuan pengendalian hama secara intensif. Selain itu faktor musim berbuah juga menyebabkan peningkatan populasi lalat buah karena inang tersedia secara melimpah sehingga persentase serangan menjadi tinggi.

Persentase serangan lalat buah di Bali yang menunjukkan variasi yang cukup besar, yaitu antara 6,4-70\% (Sarwono, 2003). Menurut Sodiq (2004), tidak jarang kerusakan yang diakibatkan lalat buah khususnya pada belimbing dapat mencapai
100\%. Kelimpahan populasi lalat buah sangat erat hubungannya dengan kelimpahan tanaman inang (Sunarno \& Popoko, 2013).

Persentase serangan dapat dipengaruhi oleh teknik pengendalian yaitu penggunan perangkap, sanitasi dan penggunaan pestisida (Vijaysegaran \& Osman, 1991 dalam Shiga, 1991) seperti diketahui bahwa tanaman belimbing merupakan tanaman rumahan yang jarang dibudidayakan secara luas dan hanya ditanam di sekitar pekarangan rumah hal ini menyebabkan jarang mendapatkan pengendalian hama dengan baik, apabila dibandingkan dengan tanaman budidaya yang lain seperti tanaman jeruk, cabai dan semangka yang mendapatkan pengendalian secara baik seperti penyemprotan dengan pestisida dan sanitasi yang menyebabkan persentase serangan lalat buah cendrung tinggi.

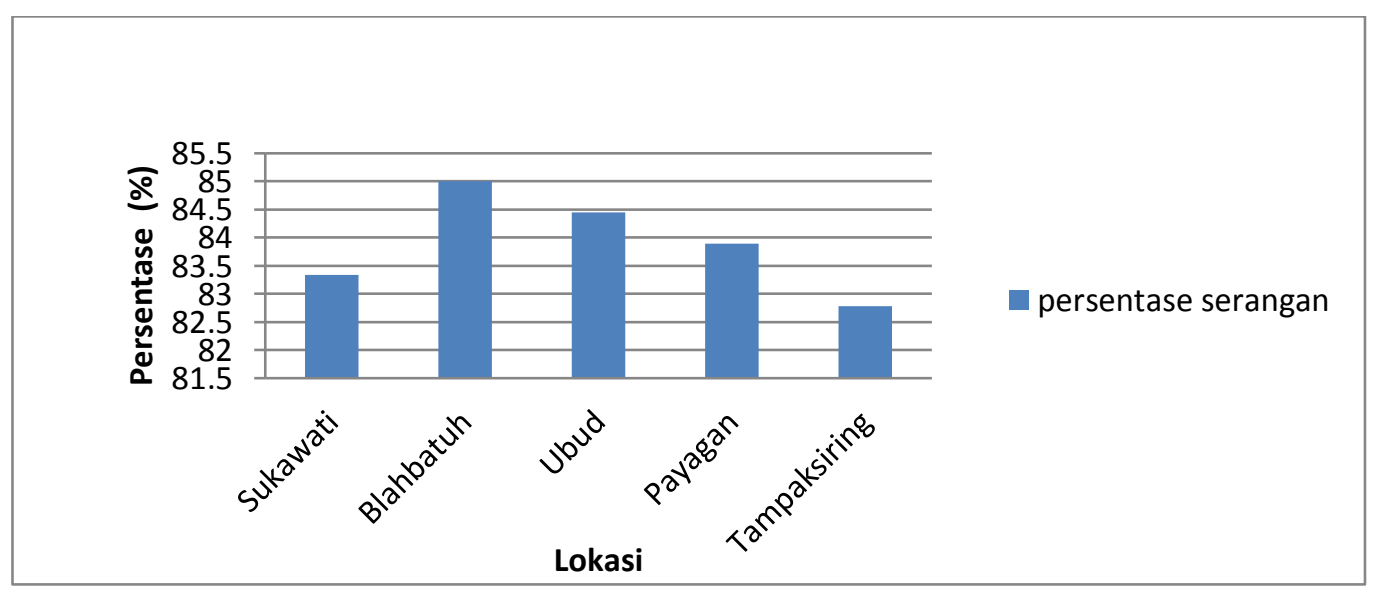

Gambar 4. Persentase Serangan Lalat Buah pada Tanaman Belimbing di Kabupaten Gianyar 
AGROTROP, 9 (1): 1 - 12 (2019)

Tabel 2. Jenis Parasitoid pada Tanaman Belimbing

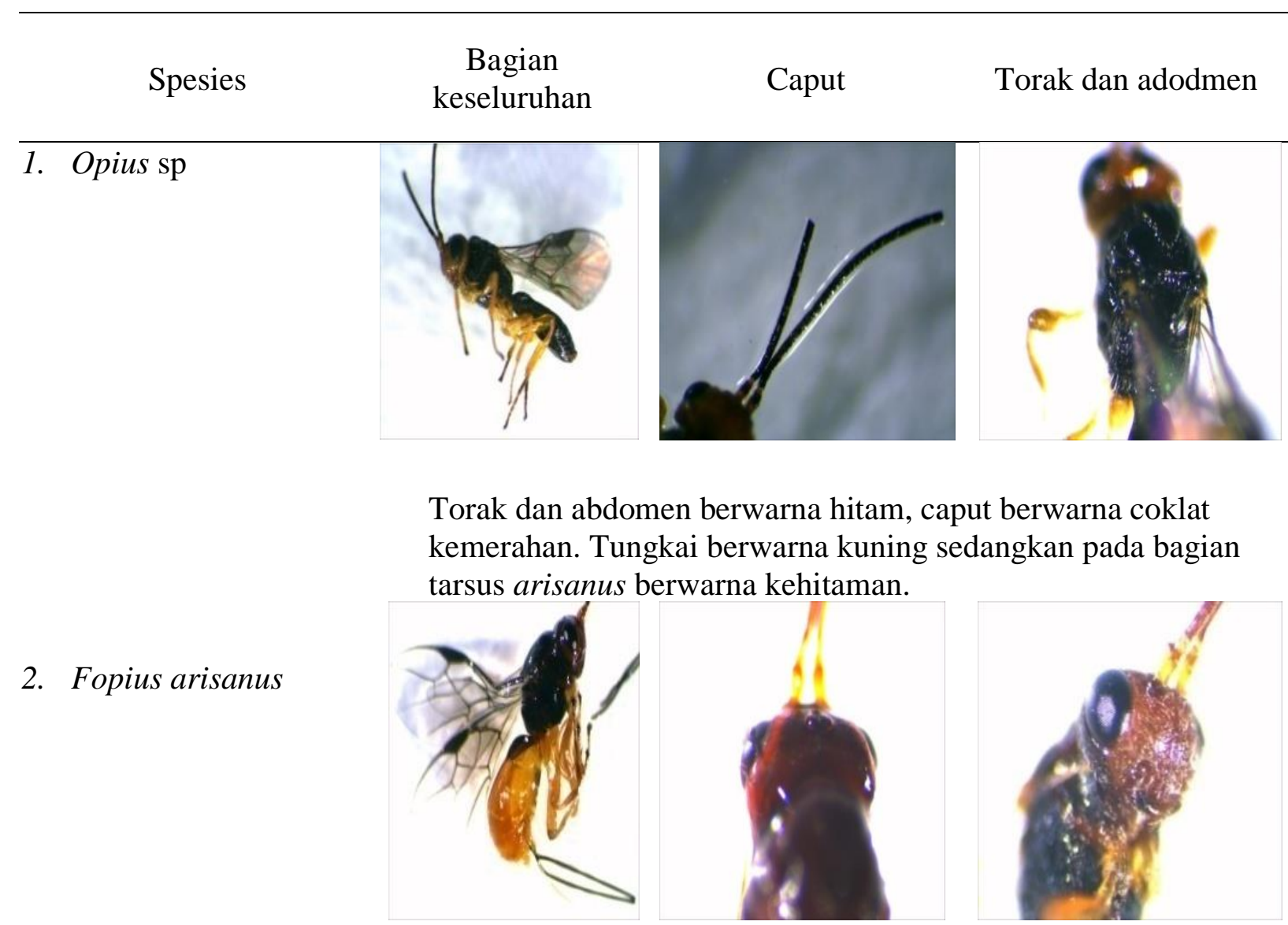

Torak berwarna hitam, abdomen berwarna oranye ke kuningan. Tungkai berwarna kuning sedangkan pada bagian tarsus berwarna kehitaman.

3. Diachasmimorpha sp
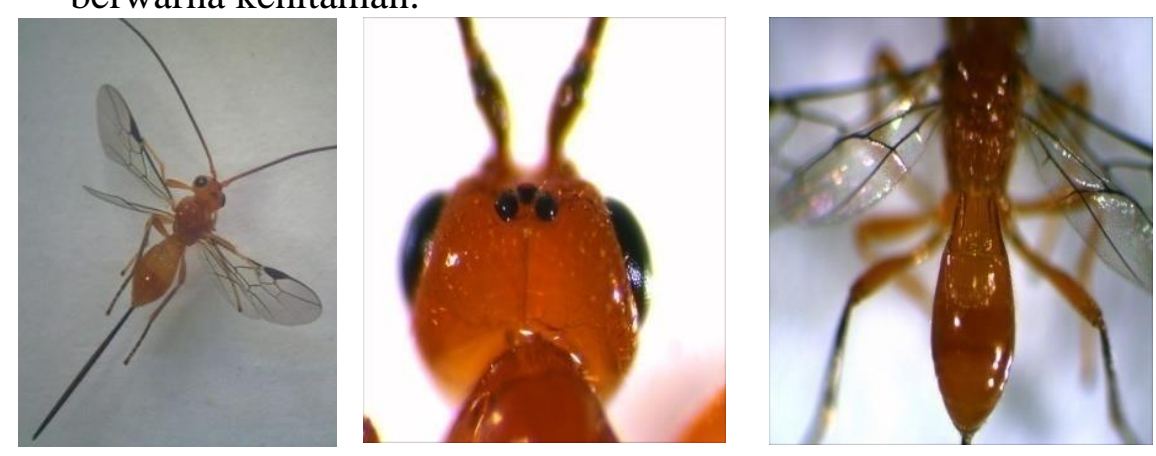

Keseluruhan bagian tubuh berwarna oranye 
I NYOMAN WIDNYANA PUTRA. et al. Kelimpahan Spesies Lalat Buah (Diptera: Tephritidae)...

Berdasarkan (Tabel 2) terdapat 3 belimbing di Kabupaten Gianyar rata-rata spesies parasitoid yang berasosiasi dengan 11,12\%. Tingkat parasitisasi parasitoid lalat buah yang menyerang tanaman paling tinggi terdapat di Kecamatan Ubud belimbing di Kabupaten Gianyar yaitu (12,40\%), di ikuti Kecamatan Blahbatuh Fopius arisanus, Opius sp. dan (11,41\%), Kecamatan Sukawati (11,41 \%), Diachasmimorpha sp.

Kecamatan Payangan (10,79 \%) sedangkan tingkat parasitisasi parasitoid paling rendah

Tingkat Parasitisasi Parasitoid pada di Kecamatan Tampaksiring (9,58 \%) Tanaman Belimbing di Kabupaten (Gambar 5.).

Gianyar

Hasil penelitian menunjukkan tingkat parasitisasi parasitoid pada tanaman

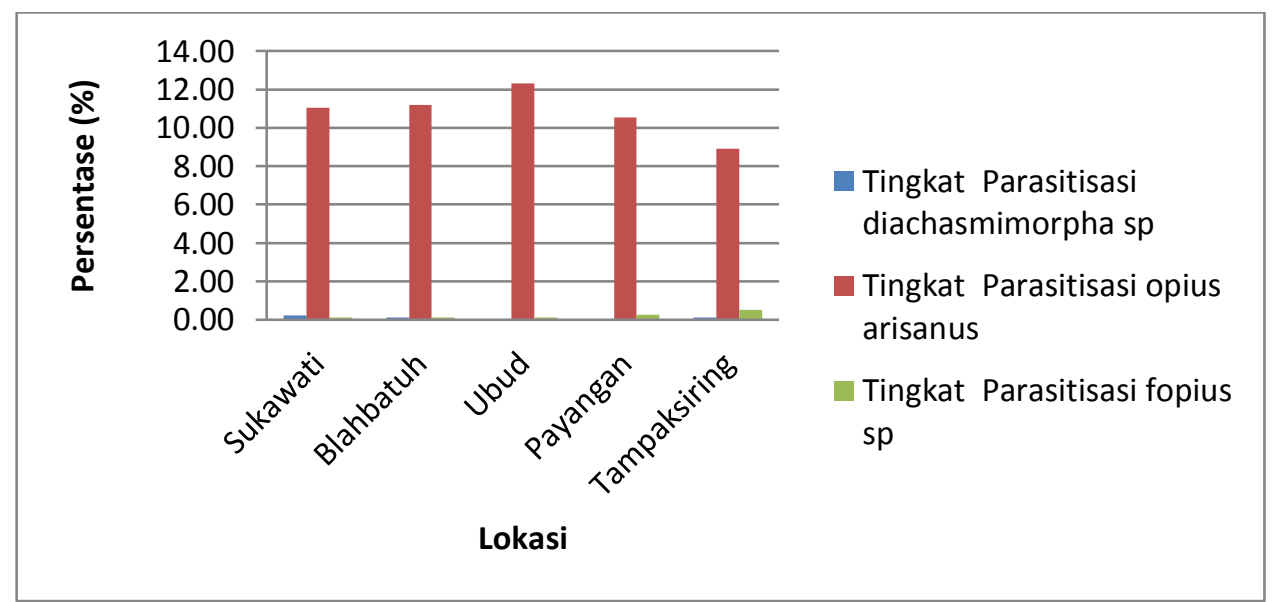

Gambar 5. Tingkat Parasitisasi Parasitoid pada Tanaman Belimbing di Kabupaten Gianyar

Berdasarkan hasil penelitian yang Herlinda et al. (2007), menyatakan dilakukan tingkat parasitisasi parasitoid pada bahwa populasi parasitoid dipengaruhi tanaman belimbing di Kabupaten Gianyar mencapai yaitu rata-rata $11,12 \%$. Menurut tanaman inang dan populasi inang. Tingkat Ardiasningsih (2006), intensitas parasitoid parasitisasi parasitoid pada tanaman pada buah belimbing 56,26\%.

belimbing tergolong tinggi disebabkan karena kelimpahan lalat buah sebagai inang parasitoid juga tinggi sehingga kesempatan 
parasitoid untuk memparasit juga tinggi. Selain itu, dengan tidak adanya intervensi pestisida kimia sintetis pada tanaman inang menyebabkan parasitoid bertahan hidup

\section{SIMPULAN}

Ditemukan dua spesies lalat buah yang menyerang buah belimbing di Kabupaten Gianyar yaitu $B$. papayae dan $B$. carambolae.B. carambolae lebih dominan dibandingkan dengan B. papayae. Rata-rata persentase serangannya mencapai $86,33 \%$. Selain ituterdapat tiga spsies parasitoid yaitu, Diachasmimorpha sp., Opius sp. dan Fopius arisanus. $F$. arisanus memiliki populasi tertinggi dibandingkan parasitoid lainya. Tingkat parasitisasi parasitoid rata-rata $11,12 \%$.

\section{DAFTAR PUSTAKA}

Ardiasningsih, N.N. 2006.Parasitasi Lalat Buah Bactrocera yang Terdapat PadaBuah yang Diperdagangkan di Pasar Buah Narmada dan Cakranegara.Skipsi tidak diterbitkan. Mataram: FKIP Universitas Mataram.

Drew, R. A., \& Hancock, D. L. (1994).The Bactrocera dorsalis complex of fruit flies (Diptera: Tephritidae: Dacinae) in Asia. Bulletin of entomological research supplement series, 2, 1-68.

Gupta, J.N. \& A.N. Verma. 1978. Screening of different cucurbit crops for the attack of the melon fruit fly, Dacus cucurbitae Coq. (Diptera: Tephritidae). Haryana J. Hort. Sci. 7: 78-82.
Hancock. 1997. Indo-Australasian Dacini Fruit Fly. CAB Internasional 1 CDROM dengan penuntun di dalammya.

Herlinda, S., et al. 2007. Populasi dan Serangan Lalat Buah Bactrocera dorsalis (Hendel)(Diptera: Tephritidae) serta Potensi Parasitoidnya pada Pertanaman Cabai (Capsicum annum L.).Seminar Nasional dan Kongres Ilmu Pengetahuan Wilayah Barat, Palembang, 3-5 Juni 2007.

Isnaini, Y.N., Indriyanti, D.R., \& Priyono, B. (2013).Identifikasi dan Kelimpahan Lalat Buah Bactrocerapada Berbagai Buah Terserang.Biosaintifika, 6(1), 3944.

Orr, A. 2002.The importance of fruit fly taxonomy in Indonesia.Makalah seminar Puslitbangtan.

Rouse P., PF. Duyck, S. Quilici and P. Ryckewaert. 2005. Adjustment of Field CageMethodology for Testing Food Attractants for Friut Flies (Diptera: Tephritidae).Ann. Entomol. Soc. Am. 98(3) : 402-408 (2005).

Sarwono. 2003. PHT Lalat buah pada mangga. Pros.Lokakarya masalah kritis pengendalian layu pisang,nematode sista kuning pada kentang dan lalat buah. Puslitbang Hortikultura. Buletin Teknologi dan Informasi Pertanian. Litbang Pertanian, BPTP -Jatim.p.142149.

Sodiq, M. 2004. Kehidupan lalat buah pada tanaman sayuran dan buahbuahan.Pros.Lokakarya masalah kritis pengendalian layu pisang, nematode sistakuning pada kentang dan lalat buah.PuslitbangHortikultura.Jakarta, $18 \mathrm{p}$.

Sunarno dan Stefen, P.2013.Keragaman Jenis Lalat Buah (Bactrocera spp) di Tobelo Kabupaten Halmahera Utara.Jurnal Agroforestri.Universitas Perdamaian Halmahera.Tobelo. Pp: 269-276 
I NYOMAN WIDNYANA PUTRA. et al. Kelimpahan Spesies Lalat Buah (Diptera: Tephritidae)...

Suputa, Cahyani, Kustaryati A, Railan M. I., Susilaningtyas, Taufiq A. 2006.Pedoman identifikasi lalat buah (Diptera: Tephritidae). Yogyakarta: UGM.

Vijaysegaran, S. and M. S. Osman. 1991. Fruit Fly in Penisular Malaysia, Their Economic Importance and Control Strategies. InChua, T.H. and S.G. Khoo (Eds.).Problem and Management of Tropical Fruit Flies. Proceeding of the International Symposium the Biology and Control of Fruit Flies.Jointly Organized by the Food and Fertilizer of Technology Center The University of The Ryukyus. The Okinawa Prepectural Government: 137-140.

White, I.M, \& Hancock. 1997. IndoAustralasian Dacini Fruit Fly. CAB Internasional 1 CD-ROM dengan penuntun di dalammya.

Whitmore, T.C. 1980. Potentially economic species of South-East Asia Forest. Bio Indonesia $7: 65-74$. 